\section{Time, Temperature, and Calcium Interact in Scald Reduction and Firmness Retention in Heated Apples}

\author{
Joshua D. Klein ${ }^{1}$ \\ Department of Agronomy and Natural Resources, Volcani Center, Bet Dagan \\ 50250, Israel
}

\section{Susan Lurie \\ Department of Postharvest Science, Volcani Center, Bet Dagan 50250, Israel}

Additional index words. Malus domestics, superficial scald

\begin{abstract}
Apple (Malus domestica Borkh. 'Grand Alexander') fruit were stored immediately at $0 \mathrm{C}$ after harvest or after being held at 38,42, or $46 \mathrm{C}$ for $\mathbf{7 2 , 2 4}$, or $12 \mathrm{~h}$, respectively. Half of each fruit lot was dipped in $1.5 \% \mathrm{CaCl}_{2}$ before storage. Heating did not appreciably affect Ca uptake into epidermal or cortical tissue. Calcium and heat treatments acted synergistically in reducing the severity of superficial scald and in retaining fruit firmness after 5 months of storage, relative to nontreated or nonheated Ca-dipped fruit.
\end{abstract}

Maintenance of high concentrations of $\mathrm{Ca}$ in apple fruit tissue results in slower softening of the fruit flesh (Ferguson, 1984) and can delay the onset of postharvest disorders such as superficial scald (Perring, 1979) and internal breakdown (Battey, 1990). Heat-treated apples (4 days at 38C before storage) remained firmer (Klein and Lurie, 1990; Liu, 1978; Porritt and Lidster, 1978) and developed less superficial scald (Lurie et al., 1990) than nontreated fruit following storage. Similar results were obtained with heat treatments of $42 \mathrm{C}$ for $24 \mathrm{~h}$ or $46 \mathrm{C}$ for $12 \mathrm{~h}$ (Klein and Lurie, 1992). Dipping heat-treated (38C for 4 days) apples in $\mathrm{CaCl}_{2}$ solutions before storage resulted in a synergistic effect on retention of fruit firmness (Lurie and Klein, 1992). We investigated whether dipping heated apples in $\mathrm{CaCl}_{2}$ decreases scald development more than either treatment alone.

'Grand Alexander' (syn. 'Caville San Saveur') apples were picked during the 1989 commercial harvest at Ramat Naftali, in the Upper Galilee, Israel. Internal ethylene was $<1 \mathrm{ppm}$ and firmness was $65 \mathrm{~N}$. The fruit were divided into eight lots of at least 80 fruit each and placed in plastic storage boxes. One lot was placed immediately into cold storage $(0 \mathrm{C}$, $90 \% \mathrm{RH}$ ), while another was dipped for $5 \mathrm{~min}$ in $1.570 \mathrm{CaCl}_{2}$ solution at ambient temperature and then placed in cold storage. The other six lots were divided into three pairs and placed in heating chambers at $38 \mathrm{C}$ for $72 \mathrm{~h}, 42 \mathrm{C}$ for 24

Received for publication 19 Jan. 1993. Accepted for publication 21 Sept. 1993. This paper is contribution no. 1011 -E, 1993 series from the Agricultural Research Organization. This research was funded in part by the United States-Israel Binational Agricultural Research and Development Fund. We thank Musia Zeidman for technical assistance. The cost of publishing this paper was defrayed in part by the payment of page charges. Under postal regulations, this paper therefore must be hereby marked advertisement solely to indicate this fact.

${ }^{1}$ To whom reprint requests should be addressed. light $)+(2 \times$ medium $)+(4 \times$ severe $)] / 4$ (Lurie et al., 1989). Firmness was measured on oppoat $20 \mathrm{C}$.

${ }^{2}$ Index $=[(1 \times$ light $)+(2 \times$ medium $)+(4 \times$ severe $)] / 4$

${ }^{\mathrm{y}} \mathrm{Rem}=$ at removed; $+1 \mathrm{wk}=$ after a further 7 days at $20 \mathrm{C}$.

${ }^{\mathrm{x}} \mathrm{SEM}=$ standard error of mean. site pared sides of the apples with a HunterSpring penetrometer (Hatfield, Pa.) with an 1 1-mm tip. Total flesh $\mathrm{Ca}$ was measured on

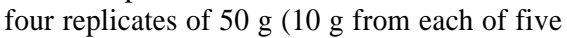
fruit) for each treatment, and peel $\mathrm{Ca}$ from four replicates of $20 \mathrm{~g}$ ( $4 \mathrm{~g}$ from each of five fruit) for each treatment. This tissue was frozen, lyophilized, acid-digested, and assayed by atomic absorption spectrophotometry. Data were subjected to analysis of variance within a completely randomized factorial design.

Dipping fruit in $\mathrm{Ca}$ raised the concentration of $\mathrm{Ca}$ in the peel by $18 \%$ to $78 \%$ and that in the flesh by $15 \%$ to $32 \%$, but the increase was not related consistently to any heating regime. The increase in the flesh $\mathrm{Ca}$ was statistically significant only for apples heated at 38C before dipping (Table 1). A Ca dip after heating enhanced the retention of fruit firmness after removal plus 7 days at 20C by 3 to $11 \mathrm{~N}$ compared to heating alone, and by 7 to 10 $\mathrm{N}$ compared to nonheated fruit. Dipping nonheated apples affected neither scald development nor firmness. The scald index of heated apples at removal from storage was reduced by $38 \%$ to $88 \%$ after Ca treatment, and by $72 \%$ to $97 \%$ compared to the control. Within heat treatments, e.g., $46 \mathrm{C}$ for $12 \mathrm{~h}$ compared to $46 \mathrm{C}$ for $12 \mathrm{~h}$ plus $\mathrm{Ca}$, the lower scald index obtained with a $\mathrm{Ca}$ dip was not significant. However, all the heat plus $\mathrm{Ca}$ treatments differed significantly from the control. Despite the overall correlation between $\mathrm{Ca}$ content of the skin and scald index after removal plus 7 days at 20C $(r=0.68, P \leq 0.05)$, regardless of temperature treatment, $\mathrm{Ca}$ dips or heat treatments alone were ineffective in moderating scald development. Adding $\mathrm{Ca}$ to heated fruit reduced scald by $42 \%$ to $74 \%$ after removal plus 7 days at 20C. This reduction was significant both within heat treatments and between fruit treated with heat plus $\mathrm{Ca}$ and controls.

The improved storage quality of fruit treated with both heat and $\mathrm{Ca}$ may be due to changes in the interactions of $\mathrm{Ca}$ with cell walls and membranes. Firmness retention as a result of the heat treatment may be caused by the en-

Table 1. Calcium content of peel and flesh, firmness, and scald index of 'Grand Alexander' apples heated at 46,42 , and $38 \mathrm{C}$ for 12,24 , and $72 \mathrm{~h}$, respectively. After heating, the apples were placed in $0 \mathrm{C}$ storage or dipped in $1.5 \% \mathrm{CaCl}_{2}$ and then stored. Fruit were removed from storage after 5 months and held 1 week

\begin{tabular}{|c|c|c|c|c|c|c|}
\hline \multirow[b]{2}{*}{ Treatment } & \multirow{2}{*}{$\begin{array}{c}\text { Peel Ca } \\
(\mathrm{mg} / 100 \mathrm{~g} \\
\text { fresh wt })\end{array}$} & \multirow{2}{*}{$\begin{array}{c}\text { Flesh Ca } \\
(\mathrm{mg} / 100 \mathrm{~g} \\
\text { fresh wt) }\end{array}$} & \multicolumn{2}{|c|}{ Firmness $(\mathrm{N})$} & \multicolumn{2}{|c|}{ Scald index ${ }^{2}$} \\
\hline & & & $\operatorname{Rem}^{y}$ & $+1 \mathrm{wk}$ & Rem & $+1 \mathrm{wk}$ \\
\hline Control & 17.7 & 5.7 & 44.8 & 39.2 & 44.4 & 77.5 \\
\hline$+\mathrm{CaCl}_{2}$ & 24.8 & 6.8 & 44.9 & 39.5 & 46.9 & 73.1 \\
\hline $46 \mathrm{C}, 12 \mathrm{~h}$ & 22.0 & 6.9 & 46.8 & 42.9 & 29.4 & 65.6 \\
\hline$+\mathrm{CaCl}_{2}$ & 25.9 & 7.9 & 50.8 & 45.9 & 10.0 & 43.8 \\
\hline $42 \mathrm{C}, 24 \mathrm{~h}$ & 15.4 & 5.5 & 42.9 & 35.5 & 21.3 & 81.3 \\
\hline$+\mathrm{CaCl}_{2}$ & 27.4 & 6.4 & 46.1 & 46.0 & 13.3 & 42.5 \\
\hline $38 \mathrm{C}, 72 \mathrm{~h}$ & 16.8 & 5.6 & 46.5 & 42.3 & 10.6 & 59.3 \\
\hline$+\mathrm{CaCl}_{2}$ & 25.5 & 7.4 & 51.5 & 49.0 & 1.3 & 20.0 \\
\hline $\operatorname{SEM}^{x}$ & 1.92 & 0.46 & 1.26 & 1.36 & 6.76 & 5.46 \\
\hline \multicolumn{7}{|l|}{ Analysis of variance } \\
\hline Temperature (T) & NS & $*$ & $* * *$ & $* * *$ & $* * *$ & $* * *$ \\
\hline $\mathrm{Ca}$ & $* * *$ & $*$ & $* * *$ & $* * *$ & NS & $* * *$ \\
\hline $\mathrm{T} \times \mathrm{Ca}$ & NS & $*$ & NS & $* * *$ & NS & $* *$ \\
\hline
\end{tabular}

Ns, ***,***Nonsignificant or significant at $\mathrm{P}<0.05,0.01$, or 0.001 , respectively. 
hancement of Ca-binding properties of certain wall fractions (Lurie and Klein, 1992). The etiology of scald in apples is hypothesized to be the oxidation of membrane lipids in epidermal and hypodermal cells followed by polymerization of polyphenols (Bramlage and Meir 1990). Membrane permeability is altered temporarily by heating (Lurie and Klein, 1990). This alteration might allow $\mathrm{Ca}$ to bind to the membrane in a way that protects against attack by free radicals and subsequent lipid oxidation and scalding.

We have previously shown that apples held at 38C for 4 days before a $3 \%$ Ca dip benefitted more from the Cathan did nonheated fruit, particularly regarding firmness retention (Lurie and Klein, 1992). Our current results show that halving the Ca concentration (from $3 \%$ to $1.5 \%$ ) also improves fruit firmness after removal plus 7 days at $20 \mathrm{C}$ when combined with either $24 \mathrm{~h}$ at $42 \mathrm{C}$ or $72 \mathrm{~h}$ at $38 \mathrm{C}$. In this experiment, synergistic benefits in apple quality maintenance occurred with a $1.5 \%$ Ca dip and at three time-temperature regimes, al though $38 \mathrm{C}$ for $72 \mathrm{~h}$ gave better results than the other heat treatments. A higher Ca-dip concentration maybe needed to obtain maximum benefit from the shorter period-higher temperature treatments.

\section{Literature Cited}

Battey, N.H. 1990. Calcium deficiency disorders of fruits and vegetables. Postharvest News \& Info. 1:23-27.

Bramlage, W.J. and S. Meir. 1990. Chillingi njury of crops of temperate origin, p. 37-50. In: C.Y. Wang (cd.). Chilling injury of horticultural crops. CRC, Boca Raton, Fla

Ferguson, I.B. 1984. Calcium in plant senescence and fruit ripening. Plant, Cell \& Environ. 7:477489.

Kfein, J.D. and S. Lurie. 1990. Prestorage heat treatment as a means of improving poststorage quality of apples. J. Amer. Soc. Hort. Sci. 103:584-587.

Klein, J.D. and S. Lurie. 1992. Prestorage heating of apple fruit for enhanced postharvest quality:
Interaction of time and temperature. HortScience 27:326-328

Liu, F.W. 1978. Modification of apple quality by high temperature. J. Amer. Soc. Hort. Sci. 103:730-732.

Lurie, S. and J.D. Klein. 1990. Heat treatment of apples: Differential effects on physiology and biochemistry. Physiol. Plant. 78:181-186.

Lurie, S. and J.D. Klein. 1992. Calcium and heat treatments to improve storability of 'Anna' apples. HortScience 27:36-39.

Lurie, S., J.D. Klein, and R. Ben Arie. 1990. Postharvest heat treatment as a possible means of reducing superficial scald of apples. J. Hort. Sci. 65:503-509.

Lurie, S., S. Meir, and R. Ben Arie. 1989. Preharvest ethephon sprays reduce superficial scald of 'GrannySmith' apples. HortScience 24:104-106.

Perring, M.A. 1979. Apple fruit quality in relation to fruit chemical composition. Acta Hort. 285:351360.

Porritt, S.W. and P.D. Lidster. 1978. The effect of prestorage heating on ripening and senescence of apples during cold storage. J. Amer. Soc. Hort. Sci. 103:584-587. 